\title{
Effect of the first and next calvings of cows and their milk production level on the relationship between dry period length and milk yield and its composition in the subsequent lactation
}

\author{
Anna Sawa, Mariusz Bogucki and Kamil Siatka \\ Department of Cattle Breeding, Faculty of Animal Breeding and Biology, University of Technology and Life Sciences in \\ Bydgoszcz, Bydgoszcz, Poland
}

\begin{abstract}
The effect cow age and milk production level was analized on the relationship between dry period length and milk yield and composition in the subsequent lactation. The GLM and CORR PEARSON procedures of the SAS package were used in the statistical calculations. It is shown that in terms of milk yield in the subsequent lactation, a dry period of 40-60 days was the most favourable. In particular in primiparous cows it was found that in terms of milk yield, shortening the dry period is less favourable than extending it beyond the 41- to 60-day standard. A dry period of 21-40 days can be offered to multiparous cows without significant milk losses in the subsequent lactation. Eliminating or shortening the dry period should exclude cows after first calving. It seems that a dry period of 21-40 days can also be offered to high-producing cows ( $\geq 8000 \mathrm{~kg}$ milk) because their milk yield, in relation to cows dried for 41-60 days, was lower by 3.5\%. Shortening the dry period has a positive effect on the concentration of basic milk components such as fat and protein, causing them to increase. Dry period length had no effect on milk lactose content.
\end{abstract}

Keywords: cows, primiparous, multiparous, dry period, milkiness 


\section{Introduction}

The dry period (the non-lactating stage in the cow's production cycle) is the time between the natural or forced end of lactation and calving. During the dry period the mammary gland goes through three stages: active involution, steady state involution, and colostrogenesis (Philpot et al. 2006). The mechanism of mammary involution suppresses milk production. During the steady state involution that lasts 2-3 weeks, mammary activity is arrested and no product is secreted (Malinowski 2004). The colostrum formation period (the last two weeks prepartum) is characterized by renewed proliferation and activity of mammary epithelium, leading to production of colostrum (Kuczaj et al. 2009), and of milk after parturition (Malinowski 2004). During this period, there are increases in volume of secretion and concentration of milk nutrients such as milk fat, lactose and casein, and a decrease in lactoferrin concentration, which is associated with the loss of antimicrobial properties, especially with regard to coliform bacteria (Philpot et al. 2006).

The optimum length of the dry period in dairy cattle has been debated since the early 19th century (Annen et al. 2004b). The 60-day dry period was adopted the beginning of the 20th century. However, the duration of this period needs to be revised because intensive breeding work that has been carried out over the last 40 years, coupled with improvements in environmental conditions caused the milk yield of cows to double in many countries. Higher milk yields increased changes in cow productivity, among others by extending lactations (Sawa \& Bogucki 2009), which possibly indicates that cows are able to produce milk for a long time, as a result of which the dry period could be shorter.

Most studies have analysed dry period length in the context of its effect on cow's milk yield in the subsequent lactation. The results show that excessively shortened or omitted dry periods cause the milk yields to vary from a $1 \%$ increase to a $10 \%$ decrease (Bachman \& Schairer 2003), with some authors reporting much higher losses of 12-40\% (Kuczaj et al. 2009, Monroe \& Amaral-Philips 2005, Philpot et al. 2006, Annen et al. 2004a, Sawa et al. 2012, McGuire et al. 2004, Rastani et al. 2005) and over $50 \%$ in the case of primiparous cows (Annen et al. 2008). More conclusive results were reported for dry periods extended beyond the 60day standard, because they all caused the milk yields to decline (Kuhn et al. 2007, Sawa et al. 2012, Berry \& Hilerton 2007, Monroe \& Amaral-Philips 2005, Waldner 2007). From an economic perspective, a discussion of milk composition may prove particularly important in countries which have milk quotas (Soleimani et al. 2010, Grummer \& Rastani 2004, Annen et al. 2004b).

The objective of the study was to analyse the effect of cow age and milk production level on the relationship between dry period length and milk yield and composition in the subsequent lactation, based on a large body of data collected from performance recorded cows.

\section{Material and methods}

Data for the study were obtained from SYMLEK database and concerned milk performance of 10139 Polish Holstein-Friesian cows representing the active population in Pomerania and Kujavia. They first calved in 2006 and were used or culled before the end of 2012. Calculations were made of the length of 18280 dry periods, which were classified by duration $(0-20,21-40$, $41-60,61-80,81-100,>100$ days). 
Analysis of variance (GLM procedure; SAS 2008) was used to evaluate the effect of dry period length in primiparous and multiparous cows and milk yield in the previous lactation $(<8000 \mathrm{~kg}$ and $\geq 8000 \mathrm{~kg}$ ) on days in milk, milk yield, and milk fat, protein, lactose and solids content in the subsequent full lactation. Significant differences were determined using the Scheffe test.

The CORR PEARSON procedure (SAS 2008) was used to calculate the coefficients of correlation between dry period length and milk yield and composition in the subsequent lactation.

\section{Results and discussion}

Out of the 18280 dry periods, most (41.5\%) were 40-60 days long and fell within the range of 6-8 weeks recommended for use in commercial practice. With the advancing age of cows, the percentage of dry periods of $0-21,21-40$ and $40-60$ days decreased and the percentage of longer periods increased (Table 1). Regardless of age, dry period length caused statistically significant differences in milk yield in the subsequent production cycle, with the largest effect observed for primiparous cows.

Independently of age, the highest milk yield was recorded in cows dried for 40-60 days. Salamończyk \& Guliński (2011) found that cows assigned a 46- to 60-day dry period were characterized by the highest energy-corrected milk yield (ECM; the amount of milk produced in relation to the amount of feed consumed) during a standard lactation and the lowest decrease in milk yield during its course. The same dry period interval was reported to be the most beneficial for the highest milk yield in the upcoming lactation by the authors cited by Gulay et al. (2003b).

Both short and extended dry periods were found to reduce milk yield in the subsequent lactation, with greater differences found for the youngest cows. In primiparous cows in particular, short dry periods were found to be less favourable in terms of milk yield than those extended beyond the 41- to 60-day standard. Reducing the dry period to 21-40 days caused the next lactation milk yield to decrease by around $6 \%$ in primiparous cows and by around $3.5 \%$ in multiparous cows. According to Church et al. (2008), shortening the dry period in primiparous cows to 30-40 days negatively affects their milk yield in the subsequent lactation, but this relationship was not observed in multiparous cows. It appears that multiparous cows can be assigned a 21- to 40-day dry period without a significant reduction in milk yield in the subsequent lactation. Likewise, Overton (2005) claims that in primiparae, the dry period can be reduced to 30-40 without affecting their next lactation performance.

Shortening the dry period to $0-20$ days in primiparous cows is not advisable because it reduces milk yield in the subsequent lactation by around $20 \%$, compared to around $16 \%$ in multiparous cows. Kuhn et al. (2005) showed that dry periods shorter than 40 days had a more negative effect on primiparous than multiparous cows, which according to the authors resulted from the differences in physiological maturity. Short or omitted dry periods can interfere with mammary development in primiparous cows, causing the milk yield to decrease in subsequent lactations (Annen et al. 2004b).

Our results show that milk yield in the subsequent lactation is adversely affected by dry periods longer than 80 days, because they reduce milk yield by around $5 \%$ regardless of 


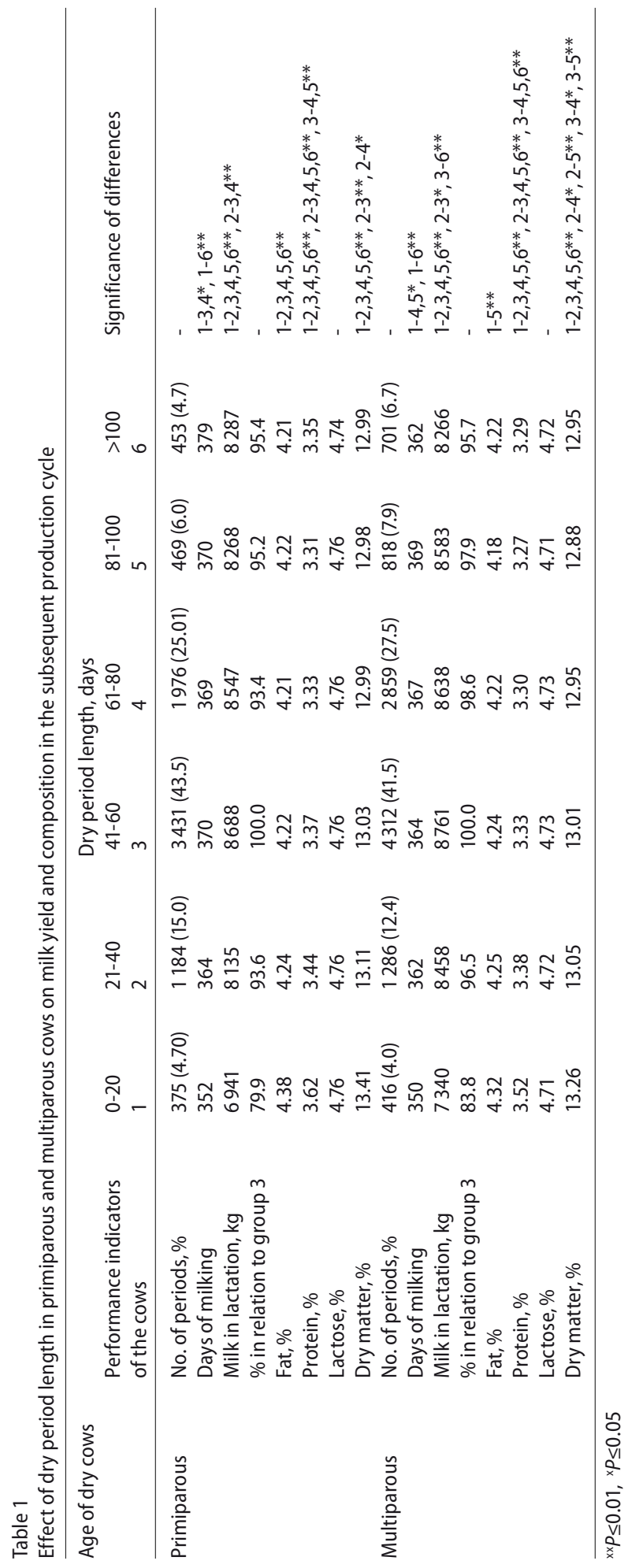


cow age. Kuhn et al. (2006) advise avoiding dry periods longer than 70 days because of a reduction in milk yield in the subsequent lactation.

Taking all the cows into account, our findings are in agreement with the results reported by Węglarzy (2009) that short ( $<1$ month) and excessively long ( $>3$ month) dry periods have negative effects on milk yield in the subsequent lactation. This also supports the earlier findings of Borkowska et al. (2006).

The main components of milk that determine its nutritional value and processing suitability are fat and protein. When analysing the effect of dry period length on milk protein content in the subsequent lactation, it was found that regardless of cow age, it was the highest when the dry period was 0-20 days. Protein content was found to decrease with the extension of the dry period, with differences between the extreme groups of $0.27 \%$ in primiparous cows and of $0.23 \%$ in multiparae. This is completely confirmed by the coefficients of correlation shown in Table 3. Grummer \& Rastani (2004) and Rastani et al. (2005) reported that shortening the dry period from 8 to 4 weeks and its elimination caused an increase in milk protein percentage, justifying it on the grounds of an inverse relationship between milk yield and milk protein percentage in response to a change in dry period length. A similar tendency was noted by Soleimani et al. (2010) who reported that the milk of cows given a 35-day dry period had a higher milk percentage compared to traditionally dried cows. Similar to Annen et al. (2004b), these authors believe that the increase in milk protein percentage may result from the decline in milk yield, which improves the energy balance and may therefore be a way of providing amino acids and energy for protein synthesis. Likewise, Bernier-Dodier et al. (2011) found milk protein content to be higher in cows dried for 35 days $(3.33 \pm 0.06 \%)$ compared to those dried for 65 days (3.14 $\pm 0.05 \%)$. Sawa et al. (2012) found protein content to decrease (from $3.54 \%$ to $3.24 \%$ ) with extension of the dry period ( 0 days - >100 days). A negative correlation $(r=-0.160 \mathrm{xx})$ between dry period length and milk protein content was reported by Borkowska et al. (2006). Also the findings of Kuhn et al. (2006) indicate that shortening the dry period had a positive effect on milk protein percentage and this pattern concerned all animals regardless of lactation number. In a study by Rémond et al. (1997), the proportion of casein in milk protein remained unchanged both in the cows managed without the dry period and in the control cows.

Changes in the fat content of milk from lactating cows after different dry period lengths were slightly smaller than for protein, but they tended to follow the same pattern, with the extension of the dry period being paralleled by a decrease in fat content (differences between the extremes groups of $0.17 \%$ in primiparous and $0.10 \%$ in multiparous cows). Borkowska et al. (2006) showed that longer extension periods were generally associated with lower fat content. A similar relationship was reported by Gulay et al. (2003a) and Rastani et al. (2005). When analysing the effect of dry period length on the nutrient content of milk from second, third and fourth lactation cows, Kuhn et al. (2006) also showed that shortening the dry period increased milk fat percentage.

Lactose content remained similar in primparous and multiparous cows regardless of dry period length. Among the studies concerning the effect of dry period length, some indicate a decrease in lactose content while others show no relationship between dry period length and lactose milk content. Annen et al. (2004a) suggest that reduced milk yield without a decrease in lactose synthesis in cows managed without the dry period may be due to the 


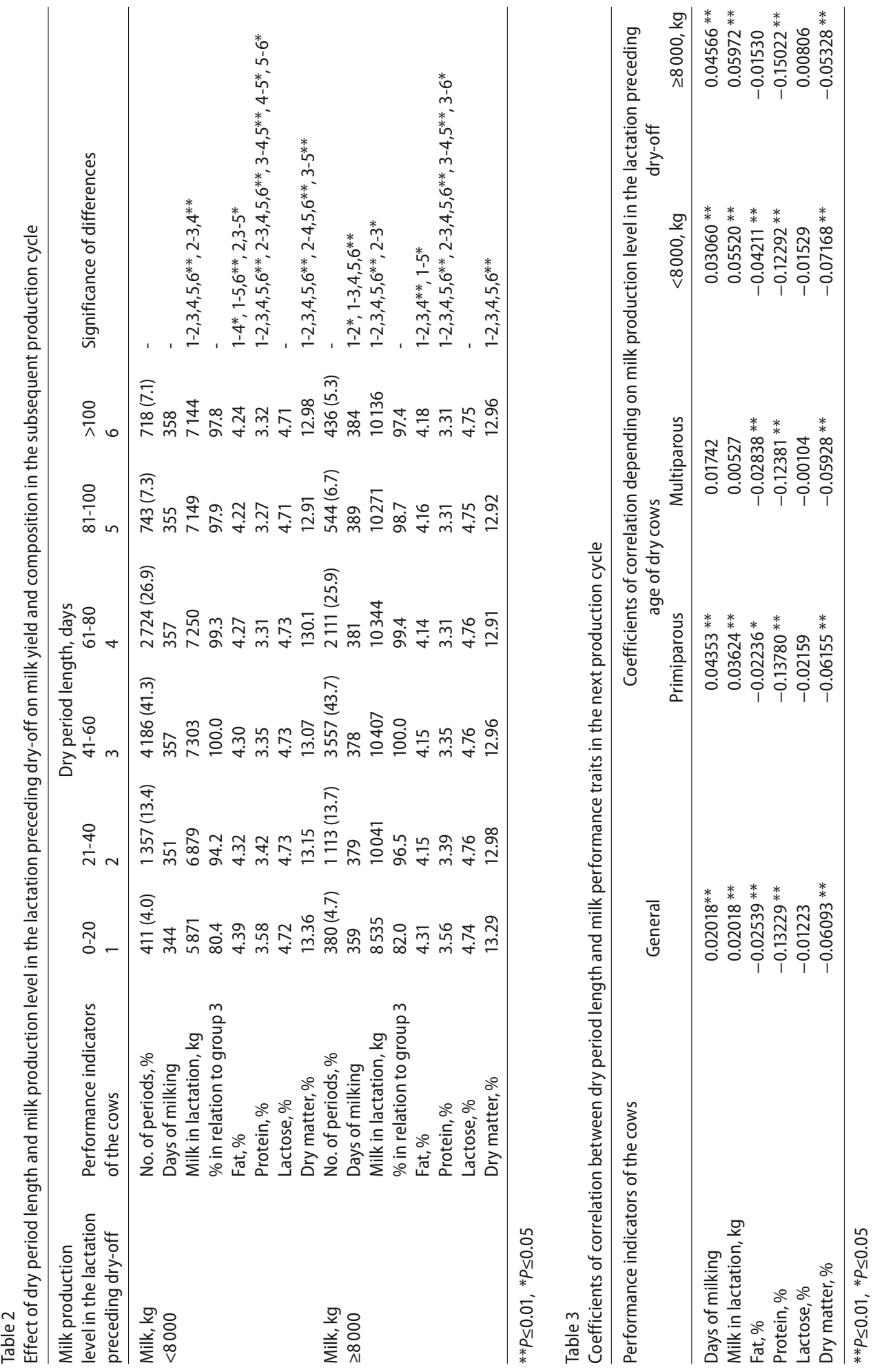


smaller number of mammary secretory cells. Bernier-Dodier et al. (2011) found no differences in lactose percentage between a 65 -day $(4.59 \pm 0.03 \%)$ and 31-day dry period $(4.57 \pm 0.04 \%)$. Meanwhile, Soleimani et al. (2010) reported that milk from cows having a traditional dry period (60 days) contained $4.56 \%$ lactose compared to $4.71 \%$ in the experimental group (35 days).

As the dry period was extended, milk solids content in the subsequent lactation decreased in both primiparous and multiparous cows, but a greater decline was noted in the group of younger cows.

It was found that with increasing milk production level during the lactation preceding drying off, the proportion of dry periods of 0-21, 21-40 and 40-60 days increased and that of longer dry periods decreased (Table 2). In the group of cows with different milk yields in the lactation preceding drying off, there was a statistically significant effect of dry period length on milk yield and composition except for lactose content. Regardless of the milk yield level in the lactation preceding the dry-off, extension of the dry period to 60-80 days and longer decreased milk yield to a small extent (around 1-2.6\%). Shortening the dry period to 21-40 days caused smaller losses (3.5\%) in the group of cows yielding $\geq 8000 \mathrm{~kg}$ milk compared to cows producing less milk (5.8\%). Also Farries \& Hoheisel (1989) showed that compared to low-yielding cows, high-producing cows are less sensitive to shortening the dry period, which the authors attribute to the effect of constant milking on milk yield in the subsequent lactation. Based on a review of literature, Kuczaj et al. (2009) suggest that cows with a daily milk yield of at least $20 \mathrm{~kg} 60$ days before calving should be further milked until, for example, 30 days before calving. The highest losses (19.6\% and 18\%) were found when the dry period was shortened to 20 days or eliminated, in which case higher-producing cows proved also less sensitive. It can be hypothesized that high-producing cows can maintain secretion even during continuous lactation, without the dry period, because selection for milk yield increased their endogenous secretion of somatotropin (Kazmer et al. 1986). Meanwhile, Kuhn et al. (2005) showed that a short dry period ( $<40$ days) for high producing cows that bred back early in lactation proved to be the worst combination in terms of maximizing subsequent lactation milk yield.

The results of many authors (Church et al. 2008, Kuhn et al. 2005, Borkowska et al. 2006, Węglarzy 2009, Sawa et al. 2012) indicate that shortening the dry period to less than 30 days limits milkyield in the next production period. Inconsistent results with regard to the effects of shortening the traditional dry period to around 30 days are described by Bachman \& Schairer (2003). Through a review of literature, they determined that shortening the dry period may cause the next lactation milk yields to vary from a $1 \%$ increase to a $10 \%$ decrease. They also showed that the results obtained can be affected by factors such as experimental approach: retrospective analysis of observational data vs. planned trials. Not without significance is the random choice of animals taking part in experiments. Other important factors affecting the results obtained include the genetic origin of cows and herd management strategies for experimental animals (Soleimani et al. 2010, Bachman \& Schairer 2003, Annen et al. 2004b).

In the group of cows which milk yield in the lactation preceding the dry period was up to $8000 \mathrm{~kg}$, the content of fat, protein and solids was found to decrease as the dry period was extended, with differences of $0.15 \%, 0.31 \%$ and $0.38 \%$ between the extreme groups. This tendency did not occur in the group of cows which milk yield in the lactation preceding 
the dry period exceeded $8000 \mathrm{~kg}$. In this group, the highest fat, protein and solids content was found for a dry period of 2-20 days; extension of this period caused the content of these components to decline, but the changes were not regular.

In summary it is concluded that in terms of milk yield in the subsequent lactation, a dry period of 40-60 days was the most favourable. In particular in primiparous cows it was found that in terms of milk yield, shortening the dry period is less favourable than extending it beyond the 41- to 60-day standard. A dry period of 21-40 days can be offered to multiparous cows without significant milk losses in the subsequent lactation. Eliminating or shortening the dry period should exclude cows after first calving. It seems that a dry period of 21-40 days can also be offered to high-producing cows ( $\geq 8000 \mathrm{~kg}$ milk) because their milk yield, in relation to cows dried for 41-60 days, was lower by 3.5\%. Shortening the dry period has a positive effect on the concentration of basic milk components such as fat and protein, causing them to increase. Dry period length had no effect on milk lactose content.

\section{References}

Annen EL, Collie RJ, Mcguire MA, Vicini JL (2004b) Effect of dry period length on milk field and mammary epithelial cells. J Dairy Sci 87, E-Suppl, 66-76

Annen EL, Collier RJ, McGuire MA, Vicini JL, Ballam JM, Lormore MJ (2004b) Effect of modified dry period lengths and bovine somatropin on yield and composition of milk from dairy cows. J Dairy Sci 87, 2746-2761

Annen EL, Stiening CM, Crooker BA, Fitzgerald AC, Collier RJ (2008) Effect of continuous milking and prostaglandin E2 on milk production and mammary epithelial cell turnover, ultrastructure, and gene expression. J Anim Sci 86, 1132-1144

Bachman KC, Schairer ML (2003) Invited review. Bovine studies on optima lengths of dry periods. J Dairy Sci 86, 3027-3037

Bernier-Dodier P, Girard CL, Talbot BG, Lacasse P (2011) Effect of dry period management on mammary gland function and its endocrine regulation in dairy cows. J Dairy Sci 94, 4922-4936

Berry EA, Hillerton JE (2007) Effect of an intramammary teat seal and dry cow therapy in relation to dry period length on postpartum mastitis. J Dairy Sci 90, 760-765

Borkowska D, Januś E, Malinowska K (2006) [Relationship between dry period lenght of cows and their productivity in subsequent lactation]. Rocz Nauk PTZ 2, 3, 27-31 [in Polish]

Church GT, Fox LK, Gaskins CT, Hancock DD, Gay JM (2008) The effect of shortened dry period on intramammary infections during subsequent lactation. J Dairy Sci 91, 4219-4225

Farries E, Hoheisel S (1989) The influence of reduced dry period on some performance and metabolism traits in dairy cows. J Dairy Sci 72 (Suppl. 1), 565

Grummer RR, Rastani RR (2004) Why reevaluate length of dry period? J Dairy Sci 87, E Suppl, E79-E85

Gulay MS, Bachman KC, Hayen MJ, Bray DR (2003a) Milk production from Holstein half-udders after concurrent 30 and 70 d dry periods. J Dairy Sci 86 (Suppl 1), 154

Gulay MS, Haydn MJ, Bachman KC, Bellono T, Libini M, Head HH (2003b) Milk production and feed intake of holstein cows given short (30-d) or normal (60-d) dry periods. J Dairy Sci 86, 2030-2038

Kazmer GW, Barnes MA, Akers MR, Pearson RE (1986) Effect of genetic selection for milk yield and increased milking frequency on plasma growth hormone and prolactin concentration in holstein cows. J Anim Sci 63, 1220-1227

Kuczaj M, Preś J, Szulc T, Twardoń J, Kinal S, Kuryszko J (2009) [An alternative drying off of high yielding cows]. Zesz Nauk UP Wroc LIX, 575, 157-174 [in Polish]

Kuhn MT, Hutchinson JL, Norman HD (2005) Minimum days dry to maximize milk yield in subsequent lactation. Animal Res 54, 351-367 
Kuhn MT, Hutchinson JL, Norman HD (2006) Effects of length of dry period on yields of milk fat and protein, fertility and milk somatic cell score in the subsequent lactation of dairy cows. J Dairy Res 73, 154-162

Kuhn MT, Hutchinson JL, Norman HD (2007) Dry period length in US Jersey: Characterization and effects on performance. J Dairy Sci 90, 2069-2081

Malinowski E (2004) Non-antibiotic protection against infection of the cow's udder during dry period. Życ Wet 79, 7, 1-8 [in Polish]

McGuire MA, Annen EL, Collier RJ (2004) Is a dry period really necessary? Adv Dairy Sci 16, 277-288

Monroe S, Amaral-Philips D (2005) Role of the dry period on future milk production. www.uky.edu/Ag/ AnimalSciences/dairy/extension/nut00063.pdf [last accessed 26.03.2011]

Overton TR (2005) Is there a place for short dry periods for high producing herds? Adv Dairy Tech 17, 25-34

Philpot WN, Nickerson SC, Malinowski E (2006) [Winning the fight against mastitis]. Westfalia Surge Polska [in Polish]

Rastani RR, Grummer RR, Bertics SJ, Gumen A, Wiltbank MC (2005) Reducing dry period length of simlify feeding transistion cows: milk production, energy balance and metabolic profiles. J Dairy Sci 88, 1004-1014

Rémond B, Kérouanton, Brocard V (1997) [The effect of reducing or omitting the dry period on the performance of dairy cows]. INRA Prod. Anim.10 (4), 301-315 [in French]

Salamończyk E, Guliński P (2011) The effect of dry period lenght on the course of milk production of Polish Holstein-Friesian var. Black-and-White cows. Acta Sci Pol Zoot 10 (3), 73-82

Sawa A, Bogucki M (2009) Effect of extended lactations on cow milk and reproductive performance. Arch Tierz $52,219-229$

Sawa A, Bogucki M, Neja W (2012) Dry period length and performance of cows in the subsequent production cycle. Arch Tierz 55, 140-147

Soleimani A, Moussavi AH, Mesgaran MD, Golian A (2010) Effects of dry period lenghton, milk production and composition, blood metabolites and complete blood count in subsequent lactation of Holstein dairy cow. World Acad Sci Engineering Technol 68, 1062-1067

Waldner DN (2007) Dry cow feeding and management. http://osufacts.okstate.edu/docushare/dsweb/Get/ Document-2035/ANSI-4260web.pdf, [last accessed 15.03.2011]

Watters RD, Wiltbank MC, Guenther JN, Bruckner AE, Rastani RR, Fricke PM, Grummer RR (2009) Effect of dry period length on reproduction during the subsequent lactation. J Dairy Sci 92, 3081-3090

Węglarzy K (2009) Lactation productivity of dairy cows as affected by the length of preceding dry period. Anim Sci Pap Rep 27, 303-309 